\title{
PRTN3 Gene
}

National Cancer Institute

\section{Source}

National Cancer Institute. PRTN3 Gene. NCI Thesaurus. Code C26589.

This gene plays a role in the growth of hematopoietic cells. 